\title{
Implementation of Gender Responsif Budget Policy
}

\author{
Nur Maghfirah Aesthetika ${ }^{1}$, Sanadjihitu Sangadji ${ }^{2}$ \\ \{fira@umsida.ac.id ${ }^{1}$, sansangadji@gmail.com² \\ Universitas Muhammadiyah Sidoarjo
}

\begin{abstract}
This research aims to discover how to gender-responsive budgeting policy is implemented in 2017 by the local government of Sidoarjo. It focuses in obtaining informations on the program and the activity within the local government environment in terms of planning and budgeting that is gender-responsive. It used descriptive in which the analysis of results is equipped with qualitative data in order to elaborate the data based on facts, data and informations. Quantitative data analysis technique is to elaborate data through statistics such as simple regression analysis and determinant analysis. The results of this research was the implementation of the program as well as the organizational operations of the local public service organizations in Sidoarjo Regency in 2017 was not sufficiently gender-responsive, and based on the quantification of the results of the gender-responsive based program and activity, it showed that the realization of gender-responsive budgeting was $52 \%$.
\end{abstract}

Keywords: Term index - Responsive-Gender Budgeting, RGB Policy, Local Government.

\section{Introduction}

Actually gender is the result or effect of sexual differentiation. Biological differences between men and women have implementation in socio-cultural life. Perception that seems to settle in the subconscious community is if a person has biological attributes, such as the penis in the male or vagina in women. Culturally, genitals are the most important factor in legitimizing gender attributes. When gender attributes are seen, at that moment too cultural construction began to form. This attribute is also always used to determine gender relations, such as the division of functions, roles and status in society[1].

The gender perspective contains the analysis of issues in social, economics, politics, law, culture and psychology to understand how differences in gender affects and are affected by policies and other practices. It analyzes how the fore-mentioned factors serve as constraints to one's opportunities and self-development[2]. While the concept of gender is a trait inherent in men and women who are constructed socially and culturally [3].

According to Sumbulah, gender responsive budgeting is a budget that is responsive to the needs of women and men and provides benefits to women and men, not a separate budget for men and women, but a strategy for integrating gender issues into the budgeting process and translating the government's commitment to realize gender equality into budget commitment [4].

It is hoped that the application of gender-responsive budgeting will take the nation in the direction of the development of a transformative society. It is undeniable that budgeting is a vital instrument of the economic policy of a government in its governing. Budlender explained 
that gender-responsive budgeting essentially speaks about the commitment of a government and translated into its budgeting policy [5].

Based on the Presidential Regulation Number 5 Year 2010 on the National Middle Term Development Plan (NMTDP) Term 2010-2014, the national government established three principal mainstreaming, i.e.: (1) Sustainable Development Mainstreaming (2) Good Governance Mainstreaming (3) Gender Mainstreaming (GM). The three principals in turn become the heart and the operational basis of the overall national development. GM is a strategy built to integrate gender perspective into an integrated dimension of planning, formulation, execution, supervision and evaluation of development policies and programs.

The evaluation on the implementation of GRPB is conducted by assessing the targeted resources used (input), targeted execution processes, targeted performances and achievements of the activities (outcome) of the GRPB. The results of that assessment are utilized by the policy-makers to assess whether the implementation of GRPB provides positive results (outcome) in the effort to materialize equality in a particular field, providing the picture of gender-responsive budgeting in each local public service organization, particularly in programs with high leverage. In conducting supervision and evaluation on the implementation of GRPB, the subjects must have an understanding of gender issues and accurately identify gender discrepancies, and are capable of showing that the objectives of the planning and budgeting program do improve gender equality.

In order to simplify and to focus on the supervision process, the implementation of GRPB is divided into stages of preparation, planning, execution and examining results of a particular GRPB. The implementation of GRPB is basically the implementation of GM strategy in the planning and budgeting stage. Therefore the requirements of implementing GM serve as inputs or as resources necessary for the execution of GRPB, which have to be found in the planning stage.

Based on the background of the problem as described above, hence the focus of the research is how gender-responsive budgeting attached to each Local Public Service Organization (LPSO) in Sidoarjo Regency has been implemented up to the present and how policies and effort made by the local government of Sidoarjo are in perfecting the gender mainstreaming policy for the following year in Sidoarjo Regency.

\section{Methods}

This research used the descriptive. The evaluation study of gender-responsive budgeting took place in Sidoarjo Regency. While the objects of study was 47 Local Public Service Organizations (LPSO) in Sidoarjo Regency.

The data collection technique used documentation, namely Local Budgeting Execution Documents (LBED) Year 2017 in Sidoarjo Regency and Action Plan and Budgeting (APB) in Sidoarjo Regency. The tecnique used to analize the data are content analysis and interactive analysis. 


\section{Results}

Many versions of the definition of the budget, but basically there are similarities. The difference lies in the side of view or different aspects. The following definitions can be more comprehensive references to understand the budget [6].

Gender Responsive Budgeting (GRB) means determining the impact of government revenue and expenditure policies on women and men. (GRB) initiatives can consist of different components and vary greatly in each country and region given their particular social, political context, and nature of their implementing agencies. These initiatives, led either by the government or civil society groups, involve examining how budget allocations affect the economic and social opportunities of women and men. This training does not aim to separate the budget for women or to argue for improving programs that are specific to women [7].

Some things can be known from the budget, namely: (1) the direction of local government policy in matters of revenue and expenditure; (2) achievement or realization of the implementation of regional government policies planned at the beginning of the budget period; (3) the capacity of local governments to implement plans that have been set up in advance; (4) the ability of local governments to choose policies that are in accordance with their capacity; (5) the ability of regional governments to maintain the sustainability of certain year's budget policies by considering the achievement of the budget in the previous period [8].

In principle, according to Sundari, the performance budget puts forward $4 \mathrm{E}$, namely economy, efficient, effectiveness and equity [9]. The responsive budget model offered consists of 4 categories, namely special budget allocations for women and children, allocations for affirmative action for marginalized groups, allocations for gender mainstreaming in the main budget, and implementation of gender mainstreaming [10].

The LPSOs assigned as sample consist of sixteen (16) local public service organizations who have programs and activities with gender-responsive budgeting and another ten (10) who do not have any. Therefore, it is concluded that the percentage of the sample of study in the evaluation of gender-responsive budgeting of the local public service organizations of Sidoarjo Regency in 2017 is as shown in Table 1:

Table 1. Recapitulation of Gender-Responsive Budgeting Year 2017 in Sidoarjo Regency

\begin{tabular}{|c|c|c|c|c|}
\hline No & Nama OPD & $\begin{array}{l}\text { Rencan Kerja } \\
\text { Anggaran (RKA) } \\
\text { Tahun } 2017\end{array}$ & $\begin{array}{c}\text { Dokumen } \\
\text { Pelaksanaan } \\
\text { Anggaran Daerah } \\
\text { (DPAD) Tahun 2017 }\end{array}$ & $\begin{array}{c}\text { Realisasi } \\
\text { Program/ } \\
\text { Kegiatan } \\
\text { (dalam } \\
\% \text { ) }\end{array}$ \\
\hline 1 & $\begin{array}{l}\text { Dinas kependudukan dan } \\
\text { Pencatatan Sipil }\end{array}$ & Rp. $\quad 543.000 .000$ & Rp. $\quad 441.700 .000$ & $81 \%$ \\
\hline 2 & Dinas Kesehatan & Rp. 335.217.728.718 & Rp. 184.631.309.196 & $55 \%$ \\
\hline 3 & Dinas Tenaga Kerja & $\begin{array}{ll}\text { Rp. } & 8.504 .392 .709\end{array}$ & $\begin{array}{ll}\text { Rp. } & 1.600 .000 .000\end{array}$ & $19 \%$ \\
\hline 4 & $\begin{array}{l}\text { Dinas Perindustrian dan } \\
\text { Perdagangan }\end{array}$ & Rp. $\quad 7.858 .265 .300$ & Rp. $\quad 1.560 .000 .000$ & $20 \%$ \\
\hline 5 & $\begin{array}{l}\text { Dinas Perpustakaan dan } \\
\text { Kearsipan }\end{array}$ & Rp. $\quad 2.941 .177 .950$ & 249.109 .000 & $8 \%$ \\
\hline 6 & $\begin{array}{l}\text { Dinas Pekerjaan Umum } \\
\text { dan Penataan Ruang }\end{array}$ & Rp. 24.975.000.000 & Rp. $\quad 8.054 .631 .000$ & $32 \%$ \\
\hline
\end{tabular}




\begin{tabular}{clrrr}
\hline $\mathbf{7}$ & $\begin{array}{l}\text { Dinas Pemberdayaan } \\
\text { Masyarakat dan Desa, } \\
\text { Pemberdayaan Perempuan } \\
\text { dan Perlindungan Anak } \\
\text { Keluarga Berencana }\end{array}$ & Rp. 6.478 .253 .000 & Rp. 6.813.179.941 & $105 \%$ \\
\hline $\mathbf{8}$ & Dinas Pendidikan & Rp. 17.736 .085 .675 & Rp. 7.744 .604 .500 & $44 \%$ \\
\hline $\mathbf{9}$ & Kecamatan Sukodono & Rp. 211.250 .000 & Rp. 110.614 .000 & $52 \%$ \\
\hline $\mathbf{1 0}$ & Kecamatan Porong & Rp. 45.505 .000 & Rp. 10.650 .000 & $23 \%$ \\
\hline $\mathbf{1 1}$ & Kecamatan Sedati & Rp. 1.176 .000 .000 & Rp. 185.500 .000 & $16 \%$ \\
\hline $\mathbf{1 2}$ & Kecamatan Sidoarjo & Rp. 92.407 .000 & Rp. 20.000 .000 & $22 \%$ \\
\hline $\mathbf{1 3}$ & Kecamatan Tanggulangin & Rp. 54.670 .000 & Rp. 37.020 .000 & $68 \%$ \\
\hline $\mathbf{1 4}$ & Kecamatan Candi & Rp. 941.074 .000 & Rp. 786.619 .500 & $84 \%$ \\
\hline $\mathbf{1 5}$ & Kecamatan Jabon & Rp. 350.700 .000 & Rp. 10.000 .000 & $3 \%$ \\
\hline $\mathbf{1 6}$ & Kecamatan Tarik & Rp. 362.190 .000 & Rp. 122.750 .000 & $34 \%$ \\
\hline
\end{tabular}

Gender-responsive budgeting in Sidoarjo Regency has been implemented in each local public service organization. The socialization of utilizing gender-responsive-based budgeting is held annually, but the realization of the program as applied at the organization level has not been optimized. Some of the constraints of implementing it at the organization level include the lack of commitment to execute gender-responsive budgeting within the overall local public service organizations; the unavailability of data classification by gender, which serves as an important indicator in the policy-making of gender-responsive budgeting; a lack of human resources as planners and persons in-charge of the program who are capable of making thorough gender analysis which will allow them to analyze and identify programs which provide equal benefits to men and women; and an absence of skill-building in supervising and evaluating gender-responsive policy, program and activity at an individual level.

\section{Conclusion}

The implementation of programs and activities of the local public service organization in Sidoarjo Regency in 2017 showed that it was not sufficiently gender-responsive. The conclusion was made on some constraints found in the field, namely: the unavailability of data classified by gender which serve as one of the important indicators in policy-making/programcreating of gender-responsive budgeting; an absence of Gender Analysis Pathways, Gender Budget Statement and framework serving as guidelines and basis of the creation of genderresponsive budgeting activities and programs; a lack of sufficient human resources performing as planners and persons in-charge who are capable of making thorough gender analysis to enable them to analize and identify the programs which provide equal benefits to the basic needs of both men and women; and an absence of skill-building in conducting supervision and evaluation on gender-responsive policy, program and activity at an individual level in the human resources.

Acknowledgments. This study will not be able to be presented without assistance from several parties, therefore, the authors express their deepest gratitude to the 16 Regional Organizations in Sidoarjo Regency and the Sidoarjo Regency Regional Development Agency 
as research objects. The researcher also expressed his deepest gratitude to the University of Muhammadiuyah Sidoarjo for providing facilities in conducting research and assisting in the process of publishing this scientific work.

\section{References}

[1] N. Umar, "Pemahaman Islam dan Tantangan Keadilan Gender, Yogyakarta: Pusat Studi Jender IAIN Walisongo dan Gama Madia." .

[2] R. Nugroho, Gender dan Strategi Pengarusutamaan di Indonesia. Yogyakarta: Pustaka Pelajar.

[3] M. Fakih, Analisis Gender dan Transformasi Sosial. Yogyakarta: Pustaka Pelajar.

[4] U. Sumbullah, "Gender dan Demokrasi, Malang: Averoes Press Berkersama Dengan Prigram Sekolah Demokrasi PlaCID"s." .

[5] E. Muslim and D. Haryadi, Memahami Anggaran Peka Gender. Bandung: Bandung Institute of Governance Studies (BIGS.

[6] B. Arifin, Panduan Analisis Anggaran. Jakarta: FITRA.

[7] D. Budlender and et all, How To Do, Gender Sensitive Budget Analysis: Contemporary Research and Practice. London: Commonwealth Secretariat.

[8] A. H. Fuady, Memahami Anggaran Publik. Yogyakarta: IDEA Press.

[9] E. K. Sundari, Anggaran Berbasis Kinerja, Gender Perspektive. Surabaya: The Asia Foundation Indonesia.

[10] S. Mastuti and Rinusu, Anggaran Responsive Gender: Konsep dan Aplikasi. Jakarta: Civic Education and Budget Traparancy Advocation. 